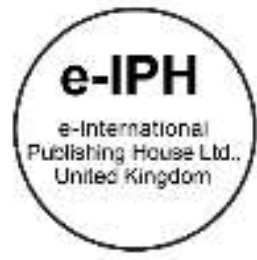

\title{
Excessive Pricing by SMEs: A Comparative Approach of Legislators' Behaviour and Sellers' Behaviour
}

\author{
Nuraisyah Chua Abdullah¹, Herwina Rosnan² \\ ${ }^{1}$ Faculty of Law \\ 2Arshad Ayub Graduate Business School, \\ Universiti Teknologi MARA, Shah Alam, 40450. Selangor. Malaysia \\ nuraisyahc@yahoo.com; nuraisyah@salam.uitm.edu.my; herwinaros@gmail.com \\ Tel: +6019-6488348
}

\begin{abstract}
SMEs contributes to $98 \%$ job opportunities in Asian businesses. However, SMEs' lack of legal knowledge on how to do business, including the issue of pricing, led to its slow growth. The legislators' behaviour of intervention or non-intervention against excessive pricing across the world reveals a spectrum of enforcement policies ranging from a clear non-interventionist approach to a moderate attitude towards the practice of the SME sellers. This paper discusses the legal aspects of excessive pricing in Malaysia where an anti-profiteering rule is provided in comparison with selected countries. Proper understanding would enable the SMEs to remain internationally competitive in the industry

Keywords: Pricing; Anti-Profiteering; Legislators' Behaviour; Sellers' Behaviour

eISSN: 2398-4287@ 2018. The Authors. Published for AMER ABRA cE-Bsby e-International Publishing House, Ltd., UK. This is an open access article under the CC BYNC-ND license (http://creativecommons. org/licenses/by-nc-nd/4.0). Peer-review under responsibility of AMER (Association of Malaysian Environment-Behaviour Researchers), ABRA (Association of Behavioural Researchers on Asians) and cE-Bs (Centre for Environment-Behaviour Studies), Faculty of Architecture, Planning \& Surveying, UniversitiTeknologi MARA, Malaysia.

DOI: https://doi.org/10.21834/e-bpj.v3i8.1388
\end{abstract}

\subsection{Introduction}

Small and medium-sized enterprises (SMEs) are the backbone of the Asian economy. They make up more than $98 \%$ of all Asian businesses that provide two out of three private sector jobs in the region. However, SMEs face challenges from several factors among others, lack of entrepreneurial zeal, capacity, and know-how, which is some of the reasons behind the slow growth of SMEs. Concerning this factor, in the SMEs, it is important to investigate the sellers' behaviour about the issue of pricing. Excessive pricing has led to legal debates on what constitutes excessive pricing in many jurisdictions. It is interesting to note that even in jurisdictions that have specific laws relating to excessive pricing, there are not many legal cases that deal with such issue. Hence, in many jurisdictions, the rules relating excessive pricing remains as ambiguous and subject to continuous debate. In view of the fact that most literature focuses on the behaviour of consumers rather than the sellers, this paper uses the qualitative and comparative study method to discuss on the behaviour of sellers in SME relation to the interventionist and non-interventionist behaviours of legislators in legal aspects of excessive pricing in Malaysia in comparison with selected countries, which have provisions of excessive pricing i.e. the UK, India and South Africa.

\subsection{Legislators' behaviour of intervention or non-intervention against excessive pricing}

Due to massive urbanisation which led to increasing living cost (Nurul Hidayah Chamhuri et al., 2012), excessive pricing has been debated over the years and Malaysia is one of the countries which has taken a big step to tackle this issue as pricing is seen as an

eISSN: 2398-4287@ 2018. The Authors. Published for AMER ABRA cE-Bsby e-International Publishing House, Ltd., UK. This is an open access article under the CC BYNC-ND license (http://creativecommons.org/licenses/by-nc-nd/4.0/). Peer-review under responsibility of AMER (Association of Malaysian Environment-Behaviour Researchers), ABRA (Association of Behavioural Researchers on Asians) and cE-Bs (Centre for Environment-Behaviour Studies), Faculty of Architecture, Planning \& Surveying, UniversitiTeknologi MARA, Malaysia.

DOI: https://doi.org/10.21834/e-bpj.v3i8.1388 
aspect which contributes to the quality of life which is highly recognised political agenda (Handan Turkoglu, 2015). Despite having the Competition Act 2010, Malaysia had introduced the Price Control Anti-Profiteering Act 2011 (hereinafter referred to as the PCAP), illustrating the interventionist approach taken by the legislators. Profiteering is an offence under the PCAP, and the PCAP is administered by the Ministry of Domestic Trade, Co-operatives and Consumerism (MDTCC). The PCAP authorises the MDTCC to monitor, control and take action against operators who impose an increase of prices of goods and services hence, leading to excessive profiteering. The purpose of the PCAP is to enable the government to determine prices of goods or charges for services with the object of preventing excessive profiteering of essential goods and services by immoral traders as provided under Section 14 of the PCAP. For the PCAP, "profiteer" means making profit unreasonably high. The considerations are as follows: (a) any tax imposition; (b) the supplier's cost; (ba) any cost incurred in the course or furtherance of business; (c) supply and demand conditions; (d) the conditions and circumstances of geographical or product market; or (e) any other relevant matters in relation to the prices of goods or charges for services.

The MTDCC also has gazetted the Price Control and Anti-Profiteering Regulations (Mechanism to Determine Unreasonably High Profit for Consumer Goods) 2016 (hereinafter referred to as the Regulations 2016) which takes into effect on 1 January 2017 which provides provisions against profiteering activities. These regulations replaced the Regulations for Price Control and Anti Profiteering (Mechanism to Determine Unreasonably High Profit) (Net Profit Margin) 2014 which was in force until 31 December 2016. The Regulations 2016 uses the formula for calculating the mark-up percentage or the margin percentage on the first day of the financial year or the calendar year to determine basic profit of the business. Profiteering occurs when the mark-up percentage or margin percentage for the current year exceeds basic profits rate in that year. Goods comprise of two categories which became the primary focus of the Enforcement and application of the Regulations 2016 are food and beverage and household items. Personal care products fall under non-durable items household goods. It appears that the legislators lay priority to items which have a direct impact on household spending and the cost of living of the people and that the legislators are not too interested to intervene into the behaviour of service providers and land vendors who practice exorbitant prices in the sale transactions. Although the enforcement of these regulations is expendable to other goods and services based on need and fairness factors, the specification of the goods and services which can be covered remains uncertain. The Regulations applies to all levels of the business for goods that fall within the scope of regulatory requirements. Any seller who sells and makes profits which is unreasonable who commits an offense and will be penalised for committing 'profiteering' under the Price Control and Anti-Profiteering Act 2011. For those SMEs who are aware of this provision, the penalty appears to be severe as for first offence, not only sellers may be fined up to maximum of RM100,000, a seller can also be imprisoned for three years imprisonment. Repeated offence may lead to the imposition of a fine of RM250,000 or imprisonment for five years or both. First offence of profiteering by a corporation or company may lead to conviction and the convicted company can be fined up to RM500,000 and repeated profiteering may lead to the imposition of a fine of RM1 million. The fact that food, beverages and household items are explicitly covered under the Regulations indicates the prevalence of excessive pricing by sellers of this category of products where one way of regulating the behaviour of the sellers are by legislative control.

However, in the United Kingdom (U.K.), there is an absence of a specific statute to tackle excessive pricing issues like Malaysia, as the U.K. solely depends on their Competition Act 1998. In contrast, India has the Competition Act 2002 and also Anti Profiteering Rules 2017. The Indian Anti-Profiteering Rules 2017 is governed under the Central Goods and Services Tax Act 2017 (hereinafter referred to as the GST Act). Under Section 171 of the GST Act, any reduction in the rate of tax on any supply of goods or services or the benefit of input tax credit shall be passed on to the recipient by way of commensurate reduction in prices. Since reduced tax rates might trigger some illegal profiteering, or traders increasing unfairly high price in the name of 'GST', therefore the Anti-Profiteering Rules came into action. Every business registered under Goods and Services Tax (GST) will fall under the purview of Anti-Profiteering Rules 2017 if any recipient of benefits makes a claim or complaint against the registered business about non-transfer of benefits under GST. In South Africa, the regulation relating to excessive pricing can be found under Chapter 2 Prohibited Practices in Part B of the South Africa Competition Act 1998. Malaysia and India share similarity where GST is one of the presumed factors which is the high possible contributor leading to excessive pricing by sellers.

\subsection{Behaviour and Responses of SMEs Business Operators/Sellers}

Due to lack of knowledge on legal aspects of business, SMEs considers the do's and don'ts in business through the lens of their moral compass. Generally, the importance of preservation of customers' choice and access to lowest price is within the understanding of the SMEs. In a survey conducted among SMEs in U.K., almost all respondents showed lack of consideration and knowledge of competition law (SMEs \& Competition Law Qualitative Research Report, 2015). Concerning price, most respondents in the study consider price fixing and market sharing as 'morally wrong'. Since the SMEs view reputation of the business as the most important motivations for businesses to comply with the law, and as such sanctions for non-compliance is important, however, the majority of SMEs insisted the importance of positive encouragements above the threat of sanctions. SMEs views that it is important to use moral and ethical values in highlighting the moral and ethical implications of breaching the law. Hence, SMEs stressed the importance of clarity of pricing laws and the obstacle of complex and complicated pricing laws. Clarity of pricing laws through education strategies, for example, workshops and roadshows can be viewed as efforts to reduce the regulatory burden on smaller firms. To address profiteering among businesses, a survey was conducted among 2,176 Malaysian SMEs' respondents in 2016 where $65 \%$ of the respondent's favour education and advise, $40.6 \%$ opine that enforcement officers should conduct more inspections and $30.2 \%$ support imposition of the higher penalty to firms who contravene excessive pricing regulation. (SME Corp. Malaysia, 2016) 


\subsection{Abuse of Dominant Position, Unfair and Economic Value}

In Malaysia, legislators view excessive pricing as an abuse of dominant position stated in Section 10 of the Malaysian Competition Act 2010. However, this provision does not expressly state the word of "excessive pricing" but expressly mentioned "directly or indirectly impose unfair purchase or selling price or other unfair trading condition on any supplier or customer" as laid down in Section 10(2) (a) of the Act 2010. SMEs which through its conduct (exploitative practices or exclusionary conduct) either independently or collectively amounts to the abuse of its dominant position commits an offence. Unfair prices or trading terms and predatory behaviour, refusal to supply or exclusive dealing are exploitative practices which are prohibited on sellers. If a seller is not the dominant enterprise or if there is competition to constrain the excessive pricing or exploitative act of the seller, then the Malaysian Competition Commission (MyCC) will not restrict the excessive pricing of the seller. Only SMEs which are dominant enterprises can be seen as abusive when the selling price is seen as abusive due to the imposition of unfair purchase or unfair trading condition on any supplier or customer. Structural conditions in the market may result in exploitative conduct. A dominant enterprise can command excessive profits where there are high barriers to entry. MyCC will consider the actual price against the costs of supply and profitability of the dominant enterprise to determine whether pricing is excessive.

In comparison with the U.K, the UK also has the same principle where the legislators view that excessive pricing can be considered as the abuse of a dominant market provided in their Chapter II of the Competition Act 1998 as follows; "directly or indirectly imposing unfair purchase or selling prices or other unfair trading conditions". In addition to the above, the legislators enact the U.K. Competition Act 1998 where excessive pricing is considered as abusive conduct.

Similarly, in India, legislators are also concerned with excessive pricing where this aspect is discussed indirectly under the Indian Competition Act 2002. Imposition of unfair price by sellers nevertheless has been explicitly stated as an abusive act under Section 4(2) (a) (ii): There shall be an abuse of dominant position, if an enterprise or a group "directly or indirectly imposes unfair or discriminatory price in purchase or sale (including predatory price) of goods or services". Unfair prices which includes excessive prices indicates that a dominant firm which abuses its dominance character. Thus, excessive price by sellers falls under the category of 'unfair price' in the Indian context, similar to Malaysia and United Kingdom. However, the legislators of Malaysia, U.K. and India have not defined 'unfair price'. Similar to Malaysia and U.K., the Indian legislators also highlights the prohibitions or the abusive conducts of 'exclusionary' and 'exploitative' practices under the Competition Act 2002. The prohibitions of both 'exclusionary' and 'exploitative' practices are set out in Section 4(2) (a), (b), (c), (d) and (e) of the Act.

In South Africa, sellers' abuse of dominance covers lists of prohibited practices which includes excessive pricing under section 8(a). Sellers are expressly prohibited from practising excessive pricing under section 8 (a) of the South Africa Competition Act 1998 as the abuse of dominance covers lists of prohibited practices which includes excessive pricing. The term 'excessive price' by sellers has been separately defined under Section 1 (1)(ix) of the Competition Act 1998 as a price for a good or service which bears no reasonable relation to the economic value of that good or service and is higher than the value. It is interesting to note that the above South Africa legal provision was derived from the European case law on excessive pricing which can be found in the case of United Brands. However, even though the legislators expressly defined 'excessive price' under the South African Competition Act, it shall be noted that there is no precise definition of 'economic value' in the Act. The ambiguity of the provision relating to excessive pricing has led to numerous debates regarding about how sellers determine the appropriate economic value of the goods or services concerned and subsequently how the reasonableness of the firm's rate of return is having regard to the price charged by the firm. Thus, the South African legislators seem to give space for the competition authority to decide the meaning of 'economic value.'

\subsection{Prohibition of Anti-Competitive Agreement}

In the context of excessive pricing, although it was neither discussed directly in the Malaysian, U.K., Indian nor South African Competition Act, the legislators in these countries nonetheless prohibited Anti-Competitive Agreements which in a way could increase the price of goods or services in the nation. Some agreements are considered to be more serious infringements of competition law than others. A serious violation is known as "hard-core cartels", are commonly referred to as price-fixing, bid-rigging, market sharing or limitation production or supply. The legislators in all these countries which have competition regime prohibit hard-core cartels. In many jurisdictions, sellers who agree to form cartels can be punished by individual fines and/or imprisonment.

SMEs who are involved in hard-core cartels like price fixing will result in higher or excessive price of goods or services in the market. In an efficient, competitive market, the forces of supply and demand will determine issues such as price. Therefore, when prices are fixed or maintained at a certain level, costs become artificial and do not truly reflect supply and demand. This would bring harm to the consumers as artificial prices usually are higher. Agreements like market sharing among sellers will harm the consumers as there will be a reduction in choice, often leading to an increase in price. When parties made agreements to limited production or supply, it will force prices up as demand will outweigh supply.

SMEs who significantly prevents restricts or distorts competition in any market for goods or services in Malaysia, or any part of Malaysia will be restrained by the Malaysian Anti-Competition Commission (MyCC). Restraining sellers from entering into hard-core cartel agreements to restrict competition is the intention of the legislators illustrated under section 4(2) of the CA 2010. It is not the intention of the legislators that MyCC is given the task to prove that the sellers' agreement has an anti-competitive effect.

In the same way, Chapter 1 of the U.K. Competition Act 1998 (section 2) prohibits any agreement or concerted practice which has the object or effect of preventing, restricting or distorting competition unless an exemption from the prohibition applies. The Indian Competition Act 2002 also prohibits anti-competitive agreements. Section 3 of the 2002 Act defines anti-competitive agreements as any agreements in respect to production, supply, distribution, storage, acquisition and control of goods or provision of services that cause 
an appreciable adverse effect on competition in India. This Section 3 deals with two kinds of agreements. Firstly, Section 3(3) of the Act deals with agreements amongst horizontally placed firms such as bid rigging, collusive bidding, cartels, etc. Secondly, agreements between firms operating at different levels in the production/distribution chain such as between manufacturers and distributors, manufacturers and retailers, distributors and retailers, etc., are subject of Section 3(4) of the Act. Unlike horizontal agreements that are considered illegal per se, an 'effects-based approach', among others, listed under Section 19(3) of the Competition Act 2002 is followed to evaluate vertical agreements as they have both positive and negative effects on competition and hence on the consumer as well.

Similarly, in South Africa, cartel behaviour is prohibited by section 4(1)(b) of the Competition Act 1998.

\subsection{Calculation of Excessive Pricing}

For the issue of excessive pricing, Malaysia had introduced the Anti-profiteering regulations while India introduced its anti-profiteering rules. However, the U.K. and South Africa do not enact any rules or regulation regarding anti-profiteering. In Malaysia, the introduction of the Anti-Profiteering Regulations (Mechanism to Determine Unreasonably High Profit for Consumer Goods) 2016 provides changes in the mechanism for determining unreasonably high profit. Under these Regulations, the determination of unreasonably high profit by sellers is done through the mark-up percentage or the margin percentage of the goods sold or offered using the prescribed formula. Rules 5 provides a method for determining that profit is unreasonably high based on the mark-up percentage of goods sold or offered for sale in a particular financial year or calendar year. Besides, Rule 6 provides a formula to determine that profit is unreasonably high based on the margin percentage of goods sold or offered for sale in a particular financial year or calendar year. Generally, "mark-up" refers to the value added by a player to the cost price of a product. The mark-up is usually added to the cost price which is equal to the retail price. For example, a company sells a bar of soap to a retailer at RM8, and it is called as a cost price. The retailer adds RM2 as his value and sells the soap to the final consumer at RM10. The margin of RM2 between the cost price and the price sell to the consumer is the "mark-up". Moreover, "margin" in the commercial context means a difference between the cost price and the selling price of a product.

In order for the price to be excessive, both the mark-up or margin percentage of any goods sold or offered for sale on any date in a particular financial year or calendar must exceed the mark-up or margin percentage of the goods sold or offered for sale on the first day of that particular fiscal year or calendar year. 43 business operators had been found guilty for profiteering as of 3 May 2017 by the Ministry of Domestic Trade, Cooperatives and Consumerism under the Price Control and Anti-Profiteering Act 2011. Offence of profiteering is seen to be committed in nine states such as Melaka, Penang, Selangor, Kuala Lumpur, Putrajaya, Kelantan, Negeri Sembilan, Kedah and Johor constituting a total of seventeen cases of profiteering. From the records, it can be seen that 8 SMEs in Melaka committed the offence of profiteering, which led to Melaka being the highest state which has committed the offence of profiteering, followed by Penang, Johor and Selangor (each with two cases), and Putrajaya, Negeri Sembilan and Kedah (each with one case).

In Malaysia, in 2016, a fine of RM15, 000.00 for an offence profiteering was imposed on the ECN World Marketing Sdn Bhd under Section 14 (1) of the Price Control and Anti-Profiteering Act 2011. The company was alleged to have raised their net profit margin for the product, when the company increased the retail price of the Lux Shower Cream (Velvet Touch) re-fill pack (600ml), from RM7.90 to RM9.40. A fine of RM 45,000 was also imposed on the chief executive officer of Kumpulan Secret Recipe Cakes and Cafe Sdn Bhd for the offence of profiteering in Shah Alam. The CEO, Sim Leong Thun was charged under Section 14 (1) of the Price Control and AntiProfiteering Act 2011 for raising the price of the Pepsi drink at the Secret Recipe Cakes and Cafe, Subang Parade branch, Subang Jaya, from RM4 to RM5 from 23 February 2015, based on the price tag exhibited. He was charged with profiteering as the price increase raised the net profit margin of the drink by 24 sen per unit, from 77 sen to RM1.01. (New Straits Times, 7 November 2016)

On the second and third charge, he was charged with profiteering over the price of a drink and a food item at the Secret Recipe Kuala Kubu Bharu branch, Jalan Mat Kilau, Kuala Kubu Bharu, from Feb 23, 2015, based on the prices that were exhibited at the premises. Sim Leong Thun was charged with increasing the price of the Iced Caffe Latte from RM7.80 to RM9, hence raising the net profit margin by 13 sen, from RM1.76 to RM1.89 for each unit. He was also charged with raising the price of Lasagna Beef from RM16.50 to RM19 and was charged with profiteering by increasing his net profit margin from RM3.72 to RM4 a unit. (New Straits Times, 7 November 2016)

In the U.K., there is neither specific mechanism or calculation provided in the UK Competition Act 1998 nor in any other regulations. Section 18 of the UK Competition Act mirrors the provisions of Article 82 and provides for the regulation of excessive pricing. UK guidelines and practice provide a restrictive approach. According to the Office of Fair Trading Guidelines on Assessment of Individual Agreements and Conduct elaborate, excessive pricing is established when the undertaking can sustain profits higher than it could expect to earn in a competitive market (supra-normal profits) and when these profits are not explainable as the result of market competition, efficiency or innovation.

Similar with the approach in the South Africa, where economic value is a determining factor, although there are the ambiguities related to what amount to 'economic value' as stated in the Act and this element was also brought to light in the cases of Mittal Steel South Africa Limited and Others v Harmony Gold Mining Company. In Mittal's case, the tribunal found out that Mittal was in the super dominant position which had adopted an import parity price as the basis for its pricing in the local market which it had identified as being naturally protected. The Tribunal took a structural approach and deduced the existence of excessive pricing by super-dominance and market segmentation. The Tribunal found out that Mittal charged the maximum possible prices due to its' dominant-position and ensured that it could reduce supply to the local market without lowering production by excluding the product from the local market through an 
exclusive export channel. The Tribunal held that the prices were not consistent with conditions of effective competition and were excessive, but the decision was overturned by the Competition Appeal Court (CAC).

The CAC believes that the excessive pricing concerns the level of prices and hence cannot be deduced from a purely structural approach like what tribunal has decided. Thus, this connotes that the structure of pricing cannot be considered per se excessive. The CAC set out four steps that must be considered in determining whether a price charged is 'excessive' within the context of the Competition Act which is as follows:

I) The actual price charged for the goods and services must be determined

II) The economic value of the good or service should be explicitly determined in monetary terms

III) A comparison must be made between the actual price and the economic cost to determine whether there is a reasonable relationship between the two prices; and

IV) That the price charged must be shown to be detrimental to consumers.

On the other hand, in India, there is no specific mechanism or calculation provided in any regulation regarding the excessive pricing as compared to Malaysia. Even though recently India had enacted a new Regulation in 2017, i.e. the Anti-Profiteering Rules 2017 where the name of the statute is similar to the Malaysian Regulations 2016, this Indian Rules focused on monitoring and checking the tax evasion and any price related difference before and after Goods and Services Tax (GST) from a particular or a list of products. However, no express provision is mentioned on how to calculate the increase in price as compared to Malaysia. The only mechanism that India used is the act of anti-profiteering will be monitored by the National Anti-Profiteering Authority (India). The Authority has a power to determine the methodology and procedure for the determination as to whether the reduction in the rate of tax on the supply of goods or services or the benefit of input tax credit has been passed on by the registered person to the recipient by way of proportionate reduction in prices. The power given to the authority is to ensure that the consumer is protected from an arbitrary price increase in the name of GST.

\subsection{Conclusion}

Since the introduction of the Malaysian Anti-Profiteering Regulations (Mechanism to Determine Unreasonably High Profit for Consumer Goods) 2016, there are criticisms of the Regulations. The rising cost of doing business/compliance cost is a point of concern, especially for the SMEs. The legislators via the regulations require a seller to provide detailed documentation relating to the calculations of its cost and selling price whenever the authority suspects an offence of excessive pricing has been committed. It also requires the compilation of more paperwork for accounting purposes to determine whether an offence of profiteering based on the formula designed in the Regulation has been committed. Therefore, SMEs need to invest bad corporate governance, but some of it has not run such strict processes. This may cause hardship to the SMEs.

The regulation also unfairly discriminate low-cost business. This is because the formula was designed to consider segmentation that is part of the market dynamics. Different businesses target different consumer segments. Some higher-income consumers prefer business which can cater them to the market greater margin such as better service, presentation or branding that businesses are serving lower income group. The regulation creates a problem when it eliminates the possibility of business cutting through the segments. In simpler terms, the restaurant owner needs to make a lot of effort that the owner of the café to get his or her margin by selling the same product.

The formula in the Regulation is said to be inflexible and can cause the inability to adapt to a market situation. For example, when an SME is facing a hard day, his business would be stuck to a rule determined on that day, resulting in the business to low profitability for the whole year. Therefore, the legislators need to be more sensitive and improve the Regulations to make it flexible and SMEs friendly. The laws of excessive pricing in the selected countries discussed in this article can be used as a comparative study in consideration of improvements in the current Malaysian Anti-Profiteering Regulations (Mechanism to Determine Unreasonably High Profit for Consumer Goods) 2016. Although the U.K. Competition Act 1998 has been gazetted ahead before Malaysia, U.K. is also facing difficulties when it comes to addressing excessive pricing issue as there is no standard guideline as to the definition of excessive pricing itself and as to the mechanism to determine the existence of excessive pricing. Each mechanism in each case differs from one another depending on the facts of the case.

Nevertheless, the latest trend by CMA in publishing the decision made on excessive pricing cases shows that the authoritative body in U.K. possess a strong voice in curbing excessive pricing as displaying the decision could set as an example and a clear warning to other companies that they would seal the same fate if they were to follow in the same path. Unfortunately, the authoritative body in Malaysia does not have such powerful impact to match with the U.K.'s CMA. However, it would be an excellent benchmark for Malaysia to look up to give better guidelines to the Malaysian SMEs as a way to regulate the SMEs behaviours. The sensitivity of excessive pricing should be instilled in the lives of the citizens and reflects on citizen's attitudes, values or worldview (Aleya Abdel-Hadi, 2012) since young, in early education as interdisciplinary synthesis is an important strength for policy framing of primary education (Smita Khan, 2014). 


\section{Acknowledgement}

The authors would like to thank the Ministry of Higher Education Malaysia for the financial support through the Fundamental Research Grant Scheme (FRGS), File No: 600-RMI/FRGS 5/3 (36/2015) and the Research Management Centre, Institute of Research Management \& Innovation (IRMI) Universiti Teknologi MARA, Shah Alam for managing the fund.

\section{References}

Aleya Abdel-Hadi. (2012). Globalization and Beyond, Procedia - Social and Behavioral Sciences 50 (2012) 11 - 19

Chan, D. Supermarket chain and director charged under Price Control and Anti-Profiteering Act. New Straits Time. (Shah Alam, 23 March 2016) <https://www.nst.com.my/news/2016/03/134640/supermarket-chain-and-director-charged-under-price-control-and-anti-profiteering> accessed on 12th December 2017

Gilo, D., \& Spiegel, Y. (2007). Excessive price regulation. In 1. Conference of Research Network on Innovation and Competition Policy: Modern Approaches in Competition Policy.

Handan Turkoglu.(2015). Sustainable Development and Quality of Urban Life, Procedia - Social and Behavioral Sciences 202 (2015) 10 - 14

K. Karunajothi, How SMEs Benefits from Competition Law?: Helping SMEs Understanding the Competition Law, SMEs Corp. Malaysia, 11 November 2016.

New Straits Times, 'Company fined RM15,000 for arbitrarily raising price of shower cream' (7 November 2016) <https://www.nst.com.my/news/2016/11/186545/companyfined-rm15000-arbitrarily-raising-price-shower-cream > accessed on

Nurul Hidayah Chamhuri et al., (2012). Conceptual Framework of Urban Poverty Reduction: A review of literature, Procedia - Social and Behavioral Sciences 68 (2012) $804-814$

Shams, H. N. (2017). 'Anti-profiteering Regulations: Effects on Consumer Prices \& Business Margins. Policy Ideas No. 47, <http://www.ideas.org.my/wpcontent/uploads/2017/12/PI47-Anti-profiteering-Regulations-v2.pdf> accessed 4 December 2017

SMEs \& Competition Law Qualitative Research Report (2015), prepared by BDRC Continental for the CMA, 15 May 2015.

Smita Khan. (2014). Evolving Consciousness in the Developing World: Analysis of national curriculum framework 2005 for enrichment of quality of life in school learning environments, Procedia - Social and Behavioral Sciences 202 (2015) 169 - 180.

Three cases under price control and anti-profiteering act to be brought to court. (Rompin, 3 May 2017)<http://www.themalaymailonline.com/malaysia/article/three-cases under-price-control-and-anti-profiteering-act-to-be-brought-to\#3tSxYJ0I0JpUAzBK.97> accessed 12 December 2017

Two firms fined RM140,000 under price control and Anti-Profiteering Act 2011. The Sundaily. (Malacca, 13 May 2015) <http://www.thesundaily.my/news/1417241> accessed 12 December 2017 